\title{
Case report of COVID-19 in a Hypertensive patient: Ayurvedic add on therapy
}

\author{
Case Report
}

\section{Anshul Chauhan1 ${ }^{*}$, Meenakshi Malik², Ashish Mehta ${ }^{3}$}

\section{Assistant Professor, Panchkarma Department, 2. Assistant Professor, Ayurved Samhita and Sidhant Department, Gaur Brahmin Ayurvedic College, Rohtak. \\ 3. Dean Academic Affairs, Professor \& HOD Panchkarma Department, Shri Krishna Ayush University, Kurukshetra, Haryana.}

\begin{abstract}
COVID-19 has affected negatively day to day life and global economy. Considering need for search of immunity modulator drugs for fighting this virus, Ayurvedic treatment was planned. 30 year old female patient, having history of the hypertension was diagnosed as a case of COVID-19 through RT-PCR. AYUSH Kwath (20 ml OD for 7 days), Sanshamani vati(2BD for 7 days), Sudarshan churn (3gm for14 days), Vit -C and Azithromycin given orally for 5 days. RT-PCR sample result was found COVID negative on $7^{\text {th }}$ day of treatment. Antipyretic, antiinflammatory, immune-modulatory activities were documented earlier of used medications which have shown beneficial result in present case also. Orally administered, add on Ayurvedic formulation exerted symptomatic relief in symptomatic COVID-19 case with pitta-kapha prakriti having co-morbidity of Hypertension. RCT needs to be conducted to validate result in larger sample which will generate evidence for support.
\end{abstract}

Key Words: Ayurveda, AYUSH Kwath, COVID-19, Sanshamani vati, Sudarshan churn.

\section{Introduction}

COVID-19 has affected negatively day to day life and global economy. Globally, as of 20 February 2021, there have been 110,224,709 confirmed cases of COVID-19, including 2,441,901 deaths, reported to WHO(1). Considering need for search of immunity boosting drugs for fighting this virus, Ayurvedic treatment was planned.

\section{Case Report}

30 year old female patient, doctor by profession, residing in Rohtak, Haryana, presented complaints of fever and bodyache since two days. On third day, there was development of loss of taste, smell. Other symptoms were headache and fatigue on and off. She had history of the hypertension last 4 years (on medication named Amlodipine 5mg, Bisoprolol 5mg). Study is carried out as per Declaration of Helsinki and consent form was taken before starting study.

\section{Family history}

NAD, Addiction: Tea (two cup two times a day).

\section{Past history}

\section{* Corresponding Author:}

Anshul Chauhan

Assistant Professor,

Panchkarma Department,

Gaur Brahmin Ayurvedic College,

Rohtak. India

Email Id: dr.anshu117@gmail.com
Exposure to COVID-19 positive patient. Migraine from $10 \mathrm{yrs}$ (not on medications).

\section{Physical examination}

Temp $-103^{\circ} \mathrm{F}$, tonsillar Cervical adenopathy was present.

- Ashtavidha Pariksha:

- Nadi (pulse) - Vatpradhan-pitta,

- Jihva (tongue) -Malavritta,

- Mala (stool) was Nirama,

- Mutra (urine) was yellow,

- Shabda (speech)-hoarse,

- Sparsa (touch)- ushna,

- Drika (eyes) - panduta,

- Akriti (body built) - madhyam.

- Prakriti (constitution) of patient was kapha-pittaja,

- Vikriti(pathogenesis) was Vata-pitta dominanat tridoshaj,

- Sara was rakta sar,

- Samhana(body composition): medium and

- Vyayam Shakti (exercise capacity) was madhyam,

- Vaya: Yuva,

- Ahara Shakti,

- Satva, Satyama, Bala (strength) were found Madhyam,

- Jarana Shakti(digestion capacity),

- Agni (metabolism) was manda (decreased) during Dashvidha Pariksha.

- Investigations: RT-PCR 
Diagnostic Focus and Assessment

RT-PCR result was positive when the nasal swab sample was tested.
Intervention given

AYUSH Kwath- $20 \mathrm{ml}$ OD for 7 days, Sanshamani vati 2BD for 7 days, Sudarshan churn for 14 days, Vit $-\mathrm{C}$ and Azithromycin given orally for 5 days.

\section{Timeline}

Figure 1: Timeline showing the result of Ayurvedic formulations on COVID-19 as add-on therapy

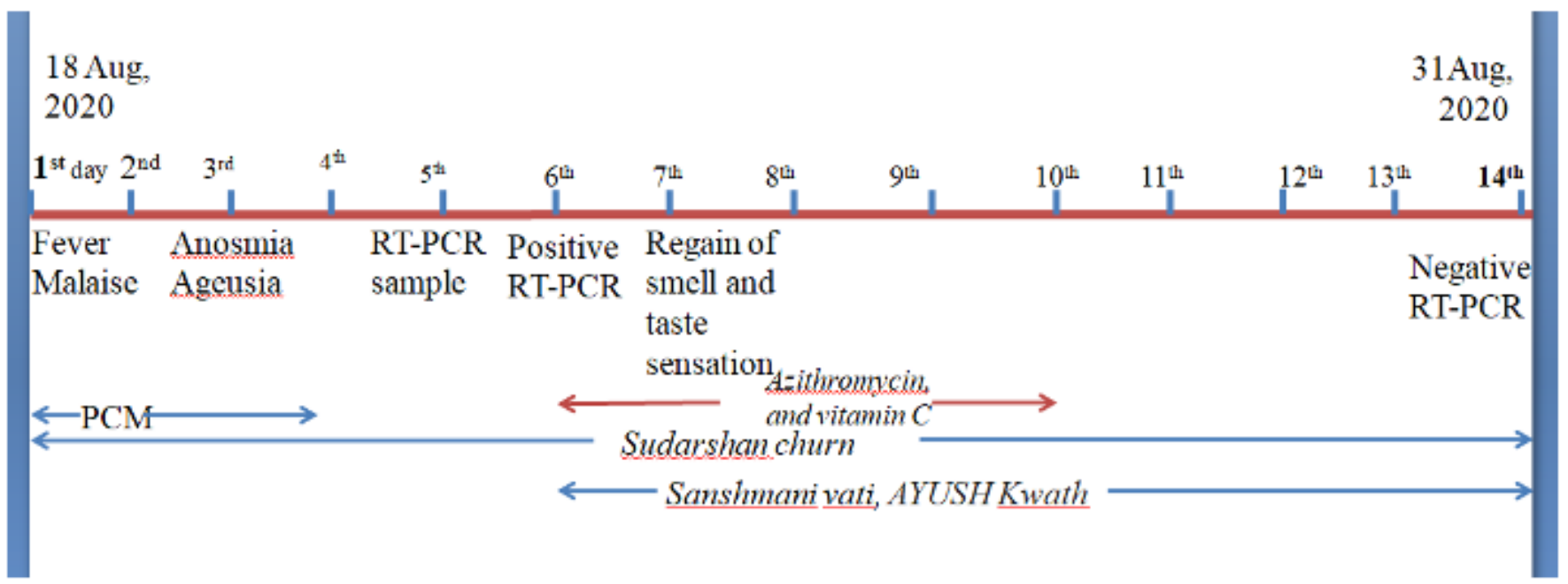

Follow up and outcome

Table 1: (Showing daily observations of vitals and others)

\begin{tabular}{|c|c|c|c|c|c|c|c|}
\hline & $24-08-21$ & $25-08-21$ & $26-08-21$ & $27-08-21$ & $28-08-21$ & $29-08-21$ & $30-08-21$ \\
\hline BP & $130 / 90 \mathrm{mmHg}$ & $124 / 90 \mathrm{mmHg}$ & $130 / 90 \mathrm{mmHg}$ & $130 / 90 \mathrm{mmHg}$ & $130 / 90 \mathrm{mmHg}$ & $130 / 90 \mathrm{mmHg}$ & $130 / 90 \mathrm{mmHg}$ \\
\hline PR & $85 / \mathrm{min}$ & $80 / \mathrm{min}$ & $82 / \mathrm{min}$ & $80 / \mathrm{min}$ & $80 / \mathrm{min}$ & $80 / \mathrm{min}$ & $78 / \mathrm{min}$ \\
\hline SPO2 & $96 \%$ & $96 \%$ & $98 \%$ & $98 \%$ & $98 \%$ & $98 \%$ & $98 \%$ \\
\hline Temperature & $103^{\circ} \mathrm{F}$ & $102^{\circ} \mathrm{F}$ & $102^{\circ} \mathrm{F}$ & $100^{\circ} \mathrm{F}$ & $99.8^{\circ} \mathrm{F}$ & $99^{\circ} \mathrm{F}$ & $98.3^{0} \mathrm{~F}$ \\
\hline RT-PCR & Positive & - & - & - & - & - & Negative \\
\hline
\end{tabular}

RT-PCR sample result was found COVID negative on $7^{\text {th }}$ day after treatment. Adherence and tolerability of intervention was assessed by the patient. There was no adverse event during treatment.

\section{Discussion}

This case was considered as significant because of fast activity of medicines in turning the positive patient with co-morbidity of HTN to negative was found. It was attempted to de-convolute the pathogenesis in the COVID-19 of the patient with multiple formulation.

Disease pathology and its Ayurvedic correlation with Sannipatika jwara in patient can be understood with presenting symptoms like coughing, fever etc.

Mechanism of used medications can be understood by following documented evidence.

Antipyretic(2), anti-inflammatory(3), immunomodulatory(4) activity of Guduchi ghana vati and beneficial effect in asymptomatic Covid-19 patients(5) documented in studies.

AYUSH Kwath herbal formulation not only modulated the pathways (HIF-1, p53, PI3K-Akt, MAPK, cAMP, Ras, Wnt, NF-kappa B, IL-17, TNF, and cGMP-PKG )related to boost the immune system but also modulated the multiple pathways that are contributing in the progression of multiple disease pathogenesis which would add the beneficial effect in the special subjects like patients from hypertension and diabetes in which 4-hydroxychloroquine therapeutic approach cannot be made(6).

Antipyretic effect(7),(8) of Sudarshan churn and its validation along anti-microbial effect through HPTLC(9), anti-oxidant potential, anti-inflammatory effect, analgesic effect, antihistamine effect (7) is well understood.

Presented Ayurvedic treatment for 7 days ameliorated the symptoms without any side effect along with change in RT-PCR. This case needs to be supported by further diagnostic findings.

In further studies, there is need to validate the findings with deeper insights.

\section{Conclusion}

Orally administered, add on Ayurvedic formulation exerted symptomatic relief in symptomatic COVID-19 case with pitta-kapha prakriti having 
comorbidity of hypertension. RCT needs to be conducted to validate result in larger sample which will generate evidence for support.

\section{References}

1. Available from: https://covid19.who.int/ on 20 Febuary,2021 at 10pm.

2. A comparative experimental study of Guduchi ghana vati prepared from fresh and dry Guduchi w.s.r. antipyretic effect August 2019;8(10):1584-90.

3. Patgiri B, Umretia BL, Vaishnav PU, Prajapati PK, Shukla VJ, Ravishankar B. Anti-inflammatory activity of Guduchi Ghana (aqueous extract of Tinospora Cordifolia Miers.). Ayu. 2014 Jan; 35(1):108-10. doi: 10.4103/0974-8520.141958. PMID: 25364210; PMCID: PMC4213960.

4. Umretia B, Vaishnav PU, Patgiri BJ, Prajapati PK, Shukla VJ, Ravishankar B. Immunomodulatory activity of Guduchi Ghana (Aqueous Extract of Tinospora Cordifolia Miers ). NJIRM. May,2013;4(3):90-6.

5. Kumar A, Prasad G, Srivastav S, Gautam VK. A Retrospective Study on Efficacy and Safety of Guduchi Ghan Vati for Covid-19 Asymptomatic
Patients. MedRxiv. September, 2020 ; doi: 10.1101/2020.09.20.20198515.

6. Khanal P, Duyu T, Patil BM, Dey YN, Pasha I, Wanjari M, Gurav SS, Maity A. Network pharmacology of AYUSH recommended immuneboosting medicinal plants against COVID-19. J Ayurveda Integr Med. 2020 Nov 25. doi: 10.1016/ j.jaim.2020.11.004. PMID: 33250601; PMCID: PMC7687402.

7. Achchige W, Saroja S, Perera PK, Gunasekera D, Suresh TS. Evaluation of the In Vitro and In Vivo Antioxidant Potentials of Sudarshana Powder. Evidence-Based Complementary and Alternative Medicine. April, 2018 . https://doi.org/ 10.1155/2018/6743862

8. Singh B, Gupta V, Bansal P, Kumar D, C MK. Pharmacological Potential of Polyherbal Formulation , Sudarshan Churna - A Review. International J.Ayur.Medi. April, 2011;2(2),52-61.

9. Kaur P, Gupta RC, Dey A, Malik T. Validation and quantification of major biomarkers in 'Mahasudarshan Churna'- An ayurvedic polyherbal formulation through chromatography. BMC Complementary Medicine and Therapies. June, 2020;20(184),1-11. 